\title{
Kasus Gigitan Ular Berbisa di Indonesia
}

\author{
Case of Venomous Snake Bite in Indonesia
}

Maula Haqul Dafa, Slamet Suyanto

\begin{abstract}
Fakultas Matematika dan Ilmu Pengetahuan Alam Universitas Negeri Yogyakarta Email: maulahaqul.2017@student.uny.ac.id
\end{abstract}

\begin{abstract}
Abstrak
Ular merupakan satwa liar yang habitatnya paling dekat dengan manusia. Gigitan ular dikategorikan WHO sebagai "Neglected Tropical Disease" atau Penyakit Tropis Terabaikan dan menyumbang kematian lebih dari 100.000 orang di seluruh dunia tiap tahun, sebagian besar berasal dari negara berkembang yang terletak di daerah tropis dengan penduduk padat. Kematian akibat gigitan ular disebabkan oleh beberapa faktor, yaitu tingkat bisa ular yang menggigit, keadaan korban, penanganan pertama, akses ke rumah sakit yang memadai, dan ketersediaan antivenom. Penanganan pertama yang tepat ketika tergigit ular berbisa adalah dengan imobilisasi, yaitu membuat bagian tubuh yang tergigit hanya bergerak seminimal mungkin atau bahkan tidak bergerak, dan mendapatkan antivenom via infus jika sudah memasuki fase sistemik. Ketidaktahuan masyarakat mengenai penanganan pertama yang tepat dan dianjurkan serta ketidaktersediaan antivenom ular yang tepat di rumah sakit dapat meningkatkan jumlah orang yang tewas akibat gigitan ular.
\end{abstract}

Kata kunci: kasus gigitan ular, bisa ular, imobilisasi, antivenom.

\begin{abstract}
Snakes are wild animals whose habitat is closest to humans. Snake bites are categorized by WHO as "Neglected Tropical Disease" and contribute to the death of more than 100,000 people worldwide each year, mostly from developing countries located in tropical regions with dense populations. Death due to snakebite is caused by several factors, namely the rate of snake bite, the condition of the victim, first treatment, adequate access to hospital, and availability of antivenom. The first appropriate treatment when bitten by a poisonous snake is by immobilization, which makes the bitten part of the body only move to a minimum or even not moving, and get antivenom via infusion if it has entered the systemic phase. Public ignorance of the first proper and recommended treatment and the unavailability of proper snake antivenom in hospitals can increase the number of people killed by snake bites.
\end{abstract}

Key words: snake bite cases, snake venom, immobilization, antivenom.

\section{PENDAHULUAN}

Ular merupakan satwa liar yang mempunyai habitat terdekat dengan manusia. Binatang ini masih dapat ditemukan di pohon-pohon yang berada di halaman rumah, di pekarangan, sawah, saluran air, bahkan terkadang masuk ke kediaman warga. Ular sendiri termasuk dalam reptilia atau hewan melata yang merupakan hewan ektotermik atau berdarah dingin. Itu berarti, ular tidak dapat memproduksi panas tubuhnya sendiri sehingga harus mengandalkan pada panas lingkungan sekitarnya agar bisa beraktivitas. Hal inilah, salah satu faktor yang menyebabkan banyak ular berada di daerah tempat tinggal manusia.

Konfrontasi manusia dengan ular terhitung sering terjadi, terutama di negara 
yang memiliki banyak populasi yang tidak terkonsentrasi di wilayah perkotaan. Konfrontasi ini sering berakhir dengan salah satu pihak yang celaka, entah pihak manusia karena digigit atau dibelit, entah pihak ular. Banyak ular yang dibunuh karena warga menggeneralisasi semua ular berbahaya, atau sekedar karena mitos yang melekat padanya.

Di negara-negara tropis, di mana kelimpahan reptilia baik dari segi spesies dan jumlah paling banyak, gigitan ular berbisa menjadi masalah yang terselubung. Setiap tahun, diperkirakan lebih dari tiga ratus ribu orang tergigit oleh ular dan lebih dari seratus ribu orang meninggal tiap tahun karena tergigit ular, sebagian besar korbannya berasal dari Asia Selatan, Asia Tenggara, dan sub-Sahara Afrika, tempat di mana pemukiman padat penduduk dikombinasikan dengan keberadaan jenis ular berbisa dan ketidaktahuan warga menangani gigitan ular, ditambah terkadang akses yang kurang memadai ke rumah sakit.

Gigitan ular merupakan salah satu masalah kesehatan yang sering terjadi di negara tropis dan subtropis. Pada tahun 2009, WHO memasukkan gigitan ular dalam daftar neglected tropical disease dan sampai sekarang tetap sebagai masalah kesehatan masyarakat global. Mayoritas penduduk Indonesia bekerja di bidang pertanian dianggap sebagai populasi berisiko tinggi untuk terkena gigitan ular. Di Indonesia tidak ada laporan epidemiologi nasional yang tersedia disebabkan oleh sistem pelaporan yang kurang akurat. Data epidemiologi kasus gigitan ular hanya dari laporan rumah sakit. Hanya ada 42 kasus gigitan ular yang diobati pada antara tahun 2004 dan 2009. Wanita lebih jarang digigit ular dibandingkan pria, kecuali pekerjaan didominasi oleh wanita. Anak-anak dan dewasa muda merupakan puncak usia yang sering digigit ular. (Suryati et al., 2018)

Gigitan ular dapat menyebabkan kerusakan pada jaringan lokal, nekrosis sel perdarahan dalam, hilangnya fungsi dari otot, pembengkakan, tekanan darah turun, kerusakan pada kornea, iritasi dan bengkak pada daerah uvea, dan pecahnya sel darah merah. Dalam penanganan gigitan ular diperlukan tatalaksana yang cepat dan dipastikan penyebab gigitan apakah disebabkan ular berbisa. Identifikasi jenis gigitan dan gejala akibat gigitan berguna dalam penegakan diagnosis maupun terapi untuk menghindari kecacatan dan keadaan yang mengancam jiwa.(Pratama, 2017)

Ular berbisa dapat dijumpai di seluruh belahan dunia, kecuali pada beberapa pulau, lingkungan dingin, dan terletak tinggi dari permukaan laut. Gigitan ular berbisa dan kematian yang diakibatkan merupakan masalah kesehatan publik yang penting pada daerah pedesaan. Populasi pada daerah ini memiliki morbiditas dan mortalitas yang tinggi karena akses pelayanan kesehatan yang buruk, yang seringkali suboptimal dan pada beberapa keadaan, kelangkaan antivenom, yang merupakan satu-satunya pengobatan spesifik.(Medikanto et al., 2017)

Korban gigitan yang selamat mengalami sekuele fisik permanen akibat nekrosis jaringan lokal, dan sekuele psikologis. Karena kebanyakan korban gigitan ular masih muda, maka pengaruh terhadap ekonomi karena disabilitas mereka perlu dipertimbangkan. Disamping besarnya efek terhadap populasi, gigitan ular tidak mendapat perhatian yang cukup dari pelayanan kesehatan nasional dan internasional, dan dapat dikategorisasi sebagai penyakit tropikal yang terabaikan.(Luman, n.d.)

\section{SOLUSI/TEKNOLOGI}

Bisa ular terdiri dari campuran beberapa polipeptida, enzim dan protein. Jumlah bisa, efek letal dan komposisinya bervariasi tergantung dari spesies dan usia ular. Bisa ular bersifat stabil dan resisten terhadap perubahan temperatur. Secara mikroskop elektron dapat terlihat bahwa bisa ular merupakan protein yang dapat menimbulkan kerusakan pada sel-sel endotel dinding pembuluh darah, sehingga menyebabkan kerusakan membran plasma. Komponen peptida bisa ular dapat berikatan dengan 
reseptor-reseptor yang ada pada tubuh korban. Bradikinin, serotonin dan histamin adalah sebagian hasil reaksi yang terjadi akibat bisa ular.(Pediatri et al., 2003)

Ular berbisa yang menggigit melakukan envenomasi (gigitan yang menginjeksikan bisa atau racun), bisa ular melewati kelenjar bisa melalui sebuah duktus menuju taring ular, dan akhirnya menuju mangsanya. Bisa ular mengandung berbagai enzim. Enzim yang dikeluarkan ini antara lain hialuronidase, fosfolipase A dan berbagai proteinase yang menyebabkan kerusakan jaringan. Bisa ular menyebar dalam tubuh melalui saluran kapiler dan limfatik superfisial. Efek lokal pada luka gigitan ular berbisa adalah terjadinya pembengkakan yang cepat dan nyeri.(Rifai \& Andriani Cholifah, 2011)

Antibisa ular adalah satu-satunya antidot efektif untuk bisa ular. Pemberian antibisa ular dilakukan sesegera mungkin sesuai indikasi. Antibisa ular dapat melawan keracunan sistemik walaupun telah terjadi selama beberapa hari. Pemberian antibisa ular diberikan selama bukti adanya koagulopati masih ada. Antibisa ular berperan dalam mengatasi koagulopati dan menurunkan udem ekstremitas yang berat. Selain menimbulkan gangguan hemostasis, keracunan sistemik bisa ular juga dapat berupa gangguan neurologis, kardiovaskular, dan cedera ginjal akut.(Putra \& Jaya, 2017)

Gigitan oleh Viperidae / Crotalidae seringkali menimbulkan gejala pada tempat gigitan berupa nyeri dan bengkak yang dapat terjadi dalam beberapa menit, bisa akan menjalar ke proksimal, selanjutnya terjadi edem dan ekimosis. Pada kasus berat dapat timbul bula dan jaringan nekrotik, serta gejala sistemik berupa mual, muntah, kelemahan otot, gatal sekitar wajah dan kejang. Pasien jarang mengalami syok, edem generalisata atau aritmia jantung, tetapi perdarahan sering terjadi. Boyer LV dkk, melaporkan bahwa dari 38 korban gigitan ular Viperidae, 29 (76\%) mengalami koagulopati, dengan 20 (53\%) terdapat beberapa kelainan komponen koagulopati (misalnya hipofibrinogenemia dan trombositopenia). Gigitan akibat Elapidae biasanya tidak menimbulkan nyeri hebat. Namun demikian tidak adanya gejala lokal atau minimal, tidak berarti gejala yang lebih serius tidak akan terjadi. Gejala yang serius lebih jarang terjadi dan biasanya gejala berkembang dalam 12 jam. Bisa yang bersifat neurotoksik, mempunyai dapat sangat cepat dalam beberapa jam, mulai dari perasaan mengantuk sampai kelumpuhan nervus kranialis, kelemahan otot dan kematian karena gagal napas.(Avau et al., 2016)

\section{HASIL DAN DISKUSI}

1. Berdasarkan pengumpulan data, diperoleh hasil sebagai berikut:

\begin{tabular}{|c|c|c|c|}
\hline $\begin{array}{l}\text { Nama } \\
\text { Korban }\end{array}$ & $\begin{array}{l}\text { Tanggal } \\
\text { Tergigit }\end{array}$ & Ular & $\begin{array}{l}\text { Tindak } \\
\text { an }\end{array}$ \\
\hline $\begin{array}{l}\text { Rendy } \\
\text { Arga } \\
\text { Yudha }\end{array}$ & $\begin{array}{l}10 \\
\text { Novemb } \\
\text { er } 2019\end{array}$ & $\begin{array}{l}\text { Ophiophag } \\
\text { us hannah }\end{array}$ & $\begin{array}{l}\text { Rumah } \\
\text { sakit }\end{array}$ \\
\hline $\begin{array}{l}\text { Dewa } \\
\text { Rizky } \\
\text { Achmad }\end{array}$ & $\begin{array}{l}\text { 12 Juli } \\
2018\end{array}$ & $\begin{array}{l}\text { Ophiophag } \\
\text { us hannah }\end{array}$ & - \\
\hline Nuryani & $\begin{array}{l}12 \\
\text { Oktober } \\
2019\end{array}$ & $\begin{array}{l}\text { Bungarus } \\
\text { candidus }\end{array}$ & - \\
\hline Syahrir & $\begin{array}{l}14 \\
\text { Desemb } \\
\text { er } 2017\end{array}$ & $\begin{array}{l}\text { Ophiophag } \\
\text { us hannah }\end{array}$ & - \\
\hline $\begin{array}{l}\text { Anang } \\
\text { Edi } \\
\text { Kurniaw } \\
\text { an }\end{array}$ & $\begin{array}{l}\text { 14 Juni } \\
2017\end{array}$ & $\begin{array}{l}\text { Bungarus } \\
\text { fasciatus }\end{array}$ & $\begin{array}{l}\text { Pawang } \\
\text {-Rumah } \\
\text { sakit }\end{array}$ \\
\hline $\begin{array}{l}\text { Abdul } \\
\text { Kholik }\end{array}$ & $\begin{array}{l}15 \\
\text { Agustus } \\
2019\end{array}$ & $\begin{array}{l}\text { Calloselas } \\
\text { ma } \\
\text { rhodostom } \\
\text { a }\end{array}$ & - \\
\hline $\begin{array}{l}\text { Rifqi A } \\
\text { S }\end{array}$ & $\begin{array}{l}15 \\
\text { Desemb } \\
\text { er } 2019\end{array}$ & $\begin{array}{l}\text { Naja } \\
\text { sputatrix }\end{array}$ & $\begin{array}{l}\text { Rumah } \\
\text { sakit }\end{array}$ \\
\hline $\begin{array}{l}\text { Nakhiro } \\
\mathrm{h}\end{array}$ & $\begin{array}{l}15 \\
\text { Desemb } \\
\text { er } 2019\end{array}$ & $\begin{array}{l}\text { Naja } \\
\text { sputatrix }\end{array}$ & $\begin{array}{l}\text { Rumah } \\
\text { sakit }\end{array}$ \\
\hline $\begin{array}{l}\text { Wa } \\
\text { Sogo }\end{array}$ & $\begin{array}{l}2 \text { Mei } \\
2019\end{array}$ & $\begin{array}{l}\text { Python } \\
\text { reticulatus }\end{array}$ & - \\
\hline Iskandar & 23 & Bungarus & Rumah \\
\hline
\end{tabular}




\begin{tabular}{|c|c|c|c|}
\hline & $\begin{array}{l}\text { Agustus } \\
2019\end{array}$ & candidus & sakit \\
\hline HTH & $\begin{array}{l}24 \\
\text { Novemb } \\
\text { er } 2019\end{array}$ & $\begin{array}{l}\text { Naja } \\
\text { sputatrix }\end{array}$ & $\begin{array}{l}\text { Rumah } \\
\text { sakit }\end{array}$ \\
\hline Anonim & $\begin{array}{l}25 \\
\text { Desemb } \\
\text { er } 2019\end{array}$ & $\begin{array}{l}\text { Bungarus } \\
\text { candidus }\end{array}$ & $\begin{array}{l}\text { Rumah } \\
\text { sakit }\end{array}$ \\
\hline $\begin{array}{l}\text { Ismi } \\
\text { Nursaub } \\
\text { ah }\end{array}$ & $\begin{array}{l}27 \\
\text { Februari } \\
2019\end{array}$ & $\begin{array}{l}\text { Naja } \\
\text { sputatrix }\end{array}$ & - \\
\hline $\begin{array}{l}\text { Bripka } \\
\text { Desri } \\
\text { Sahroni }\end{array}$ & $\begin{array}{l}27 \text { Juli } \\
2019\end{array}$ & $\begin{array}{l}\text { Acantophis } \\
\text { laevis }\end{array}$ & $\begin{array}{l}\text { Rumah } \\
\text { sakit }\end{array}$ \\
\hline $\begin{array}{l}\text { Tirta } \\
\text { Satria }\end{array}$ & $\begin{array}{l}29 \\
\text { Desemb } \\
\text { er } 2019\end{array}$ & $\begin{array}{l}\text { Naja } \\
\text { sputatrix }\end{array}$ & $\begin{array}{l}\text { Rumah } \\
\text { sakit }\end{array}$ \\
\hline $\begin{array}{l}\text { Usman } \\
\text { Tambusa } \\
\text { i }\end{array}$ & $\begin{array}{l}3 \\
\text { Novemb } \\
\text { er } 2019\end{array}$ & $\begin{array}{l}\text { Naja } \\
\text { sputatrix }\end{array}$ & $\begin{array}{l}\text { Rumah } \\
\text { sakit }\end{array}$ \\
\hline Utami & $\begin{array}{l}4 \\
\text { Agustus } \\
2018 \\
\end{array}$ & $\begin{array}{l}\text { Naja } \\
\text { sputatrix }\end{array}$ & Tabib \\
\hline $\begin{array}{l}\text { Perment } \\
\text { ul }\end{array}$ & $\begin{array}{l}4 \\
\text { Agustus } \\
2019\end{array}$ & $\begin{array}{l}\text { Naja } \\
\text { sumatrana }\end{array}$ & - \\
\hline Rizki & $\begin{array}{l}4 \\
\text { Februari } \\
2018 \\
\end{array}$ & $\begin{array}{l}\text { Naja } \\
\text { sputarix }\end{array}$ & $\begin{array}{l}\text { Rumah } \\
\text { sakit }\end{array}$ \\
\hline MHA & $\begin{array}{l}7 \\
\text { Novemb } \\
\text { er } 2017\end{array}$ & $\begin{array}{l}\text { Trimeresur } \\
\text { us } \\
\text { albolabris }\end{array}$ & Pawang \\
\hline Ichwan & $\begin{array}{l}4 \\
\text { Januari } \\
2020\end{array}$ & $\begin{array}{l}\text { Bungarus } \\
\text { candidus }\end{array}$ & $\begin{array}{l}\text { Rumah } \\
\text { sakit }\end{array}$ \\
\hline
\end{tabular}

Korban gigitan ular memiliki jenis kelamin dan rentang usia yang bervariasi mulai dari anak-anak hingga lansia. Sebagian besar korban mengalami gigitan ular secara tidak sengaja atau murni kecelakaan, yaitu saat berada di kebun, rumah, atau hutan. Dari dua puluh satu korban, terdapat enam orang yang merupakan korban gigitan ular akibat atraksi (snake show) baik saat disaksikan orang banyak maupun karena kecerobohan korban dalam menangani ular. Hanya empat dari dua puluh satu korban yang selamat sedangkan sisanya meninggal dunia.
Gigitan ular yang merupakan kecelakaan terjadi karena konfrontasi manusia dengan ular, umumnya terjadi pada musim penghujan ketika telur-telur ular menetas atau ketika induk-induk ular mencari tempat bersarang yang terkadang akhirnya berada di dekat tempat tinggal manusia.

Meskipun penelitian ini hanya mencakup gigitan ular berbisa, terdapat satu kasus yang melibatkan Python reticulatus (ular sanca kembang) yang tidak berbisa karena ular tersebut tumbuh cukup besar untuk memangsa manusia. Bahkan, hampir setiap tahun di Indonesia terdapat kasus $P$. reticulatus yang memangsa manusia. Seperti yang tertera pada tabel, kebanyakan ular yang berkonfrontasi dengan manusia berasal dari famili Elapidae dan sedikit saja yang berasal dari famili Viperidae. Hal tersebut karena ular-ular dari famili Elapidae lebih aktif, agresif, dan gesit, serta memiliki cara berburu mengejar jejak mangsa, serta memiliki wilayah jelajah yang lebih luas dibanding Viperidae. Sementara itu, Viperidae umumnya berburu dengan menunggu mangsa di satu titik, sehingga kemungkinan untuk berkonfrontasi dengan manusia lebih kecil. Dari famili Elapidae, ular terbanyak adalah kobra jawa (Naja sputatrix) karena kobra jawa mampu menyesuaikan diri dengan baik di lingkungan manusia. Salah satu faktornya adalah makanan kobra jawa yang berupa binatang pengerat seperti tikus, yang banyak ditemukan di lingkungan manusia.

Sementara itu, kasus yang melibatkan Ophiophagus hannah atau ular raja kobra lebih jarang terjadi, karena kasus ini biasanya melibatkan ular raja kobra yang digunakan untuk atraksi dan bukan pertemuan aksidental di habitat ularnya sendiri. Kasus yang melibatkan ular dari genus Bungarus (ular welang, ular weling) juga banyak terjadi, namun tidak sebanyak ular kobra. Hal ini karena karakter ular welang dan weling umumnya pemalu dan memilih menghindar dari manusia. Acantophis laevis (Death adder) tercatat karena kasusnya yang tenar di internet dan 
ular tersebut berasal dari Indonesia bagian timur (Pulau Papua). Hanya terdapat dua spesies ular dari famili Viperidae dalam dua puluh kasus tersebut, yaitu Calloselasma rhodostoma (viper tanah) dan Trimeresurus albolabris (viper mulut putih). $C$. rhodostoma berdiam di tanah yang ditutupi serasah, sedangkan T. albolabris beraktivitas di pohon. Manusia umumnya tak sengaja menginjak atau menyenggol ular-ular ini karena ketidaktahuan dan ketidakwaspadaan, berkat kamuflase kedua jenis ular ini yang cukup baik, dan akhirnya tergigit.

Jika dilihat dari cara penanganan awal, sebagian besar korban atau orang di sekitar korban sudah mengerti bahwa penanganan teraman adalah dengan pergi ke rumah sakit, meskipun masih ada yang melarikan korban ke tabib, dukun, atau pawang ular. Hal tersebut dikarenakan kepercayaan dan kearifan lokal yang masih cukup besar. Namun, berdasarkan data di atas, tidak ada korban selamat yang berasal dari penanganan tradisional tersebut. Ketiga korban selamat adalah mereka yang mendapatkan perawatan di rumah sakit dan penyuntikan antibisa ular. Sebagian besar korban yang lain meninggal karena tidak mendapatkan penanganan pertama yang tepat, tidak mencapai rumah sakit pada waktunya, tidak mendapatkan antibisa ular, atau jarak waktu yang terlalu lama antara digigit dengan penanganan, biasanya karena korban tidak merasakan gigitan ular dan baru bertindak setelah ada gejala yang muncul.

Meskipun demikian, data di atas masih tergolong bias karena tidak semua kasus gigitan atau konfrontasi ular dengan manusia dilaporkan dan tercatat dari 20172019, sehingga analisis di atas dapat berubah jika didapatkan data yang lebih lengkap dan akurat. Sebagian besar data yang diperoleh merupakan kasus yang viral atau terkenal karena korban yang digigit dan rekaman yang beredar luas di media sosial, misalnya kasus Iskandar, seorang satpam perumahan di Serpong, Tangerang Selatan, karena salah menangani ular weling, dan
Bripka Desri Sahroni, yang meninggal karena tergigit death adder saat bertugas jaga di Mimika, Papua. Karena itu, kasus dengan gigitan ular yang sama bisa tidak tercatat jika tidak terangkat ke media, yang menyulitkan pembuatan data.

\section{KESIMPULAN}

Ular yang berkonfrontasi dan menggigit manusia kebanyakan berasal dari famili Elapidae, dan sebagian dari Viperidae, dan dapat disebabkan karena keteledoran pemelihara ular ataupun murni kecelakaan. Genus ular terbanyak yang menggigit adalah Naja atau kobra. Penanganan gigitan ular di Indonesia masih terbatas pada penanganan tradisional dan penanganan rumah sakit. Tidak semua rumah sakit di Indonesia mempunyai stok antibisa ular.

\section{UCAPAN TERIMA KASIH}

Pelaksanaan kegiatan ini dapat terlaksana karena kerjasama semua pihak. Kami mengucapkan terimakasih.

\section{PUSTAKA}

Avau, B., Borra, V., Vandekerckhove, P., \& Buck, E. De. (2016). The Treatment of Snake Bites in a First Aid Setting : A Systematic Review. 1-20. https://doi.org/10.1371/journal.pntd.00 05079

Luman, A. (n.d.). Gigitan ular berbisa. 121.

Medikanto, A. R., Matthaeus, L., Vanende, M., \& Sutarni, S. (2017). Viperidae Snake Bite: Kasus Serial Viperidae Snake Bite : Case Series. April, 361374.

Pediatri, S., Niasari, N., \& Latief, A. (2003). Gigitan Ular Berbisa. 3.

Pratama, G. Y. (2017). Gigitan Ular padaRegio Manus Sinistra Snake BiteRegio Manus Sinistra. 7, 33-37.

Putra, A. A. G., \& Jaya, S. (2017). Tata laksana gigitan ular yang disertai sindrom kompartemen di ruang terapi 
intensif. September 2016.

https://doi.org/10.15562/medicina.v47i

2.90

Rifai, A., \& Andriani Cholifah, T. (2011).

Perbedaan Antara Penanganan Luka

Snake Bite Dengan Insisi dan Tanpa

Insisi Terhadap Kecepatan Penurunan

Pembengkakan Luka Di Rsud Pacitan
Akhmad Rifai,Tri Andriani Cholifah. 36-44.

Suryati, I., Yuliano, A., \& Bundo, P. (2018). Hubungan Tingkat Pengetahuan dan Sikap Masyarakat Dengan Penanganan Awal Gigitan Binatang. 1(1). 